\title{
Stress-inducing factors among occupational drivers in Karachi, Pakistan
}

Mirza Shahrukh, ${ }^{1}$ Mehak Pervaiz ${ }^{2}$ and Naushaba Khatoon ${ }^{2}$

${ }^{1}$ The Indus Health Network, Indus Hospital, Karachi, Sindh, Pakistan. ${ }^{2}$ APPNA Institute of Public Health, Jinnah Sindh Medical University, Karachi, Sindh, Pakistan (Correspondence to Mehak Pervaiz: mehak_pervaiz@hotmail.com).

\begin{abstract}
Background: Work-related stress has become a global public health problem among occupational drivers. However, it is a highly neglected topic in the Pakistani population.

Aims: This study was conducted to identify the stress-inducing factors in occupational drivers in Karachi and to determine the relationship of stressors with sociodemographic and occupational factors among bus, minibus, rickshaw, taxi and private vehicle drivers.

Methods: A cross-sectional survey was conducted from February to October 2017 through a validated structured questionnaire. A total of 384 occupational drivers were recruited through non-probability quota sampling. Information on sociodemographic characteristics, medical history and stress-inducing factors in drivers was obtained. Statistical analysis was conducted using SPSS, version 21. The Chi-squared test was applied to see the association between categorical variables.
\end{abstract}

Results: Traffic jam was the most significant cause of stress $(n=377,98.2 \%)$, followed by condition of the roads $(n=356$, 92.7\%) and the lights of other vehicles $(n=339,88.3 \%)$.

Conclusion: Numerous stress-inducing factors are experienced by occupational drivers in Karachi. This could possibly result in decreased precision and judgment while driving resulting in increased number of accidents.

Keywords: occupational drivers, work-related stress, stress-inducing factors

Citation: Shahrukh M; Pervaiz M; Khatoon N. Stress-inducing factors among occupational drivers in Karachi, Pakistan. East Mediterr Health J. 2020;26(10):1233-1241. https://doi.org/10.26719/emhj.20.059

Received: 19/11/18; accepted: 12/06/19

Copyright ( ) World Health Organization (WHO) 2020. Open Access. Some rights reserved. This work is available under the CC BY-NC-SA 3.0 IGO license (https://creativecommons.org/licenses/by-nc-sa/3.o/igo)

\section{Introduction}

Stress is an adverse reaction, causes serious diseases and accelerates the biological aging process in humans (1). The effects of stress are not limited to physiological changes, it also affects mental and behavioural characteristics, including attitude, increased intolerance, eating pattern, quality of sleep, power of decision-making and memory and reduces a person's ability to perform at optimum levels $(2,3)$. Stress at the work place has become a global public health problem and in comparison with other professions, absenteeism due to illness and rate of disability is higher among occupational drivers (4). The adverse health impact of driving may be due to the sedentary nature of the job, increasing the risk of noncommunicable diseases or as a result of lack of time for physical activity or other health promoting behaviours (5). Driving also acts as a cumulative chronic stressor contributing to negative health outcomes (6).

Among occupational drivers, work stress is directly correlated with driving stress, as a result of which they become dysfunctional and experience reduced efficiency, which is detrimental for their profession (7). Consequently, stress-inducing factors result in dangerous driving behaviour and road traffic accidents among professional drivers, which are associated with 50 million injuries per year worldwide, a considerable portion of global disability burden (8). In addition to work stress, sociodemographic factors, including personality traits, age and driving experience, also influence a driver's risky behaviour on the road $(9,10)$. Recognizing different stress inducers among drivers is crucial as they result in different effects and require different strategies to counteract them (7).

In the setting of Karachi, which had a population of about 23.7 million in 2014, a total of 2.6 million vehicles were registered in 2011, and driving is considered to be a stressful occupation $(11,12)$. However, there is scarcity of data evaluating the stressors among occupational drivers in Karachi. Unfavourable working environments have a definite impact not only on the work quality but also on the physical and mental health of occupational drivers and therefore it is crucial to identify stress-inducing factors in occupational drivers as the risk of having an accident increases under stressful condition $(13,14)$.

The objectives of this study were to identify stressinducing factors among occupational drivers (bus, minibus, rickshaw, taxi and private vehicle) in Karachi and to determine any correlation of stressors with sociodemographic and occupational factors among occupational drivers. 


\section{Methods}

This cross-sectional study was conducted from February to October 2017 and included bus, minibus, rickshaw, taxi and private vehicle occupational drivers in Karachi. The drivers were selected through quota sampling technique which allowed comparison among stressors experienced by bus, rickshaw, taxi and private vehicle drivers. Four quotas were formed consisting of 96 occupational drivers in each quota, making a total sample size of 384 drivers; this was calculated using OpenEpi (at 50\% anticipated frequency). Occupational drivers who were $\geq 18$ years old and who drove vehicles as a part of their work for $\geq 6$ hours daily and with $\geq 1$ year of experience (irrespective of their vehicle ownership) were included. Drivers who refused to give informed consent or had any diagnosed mental illnesses or any history of psychological or emotional problems were excluded.

A self-administered questionnaire was used to collect detailed information on sociodemographic characteristics, medical history and stress-inducing factors. A Likert scale was used for checking the severity of the stressor (15). Questions were adapted and modified from relevant previous studies $(16,17)$. For the face validity of the questionnaire, public health professionals were asked to review it. The questionnaire consisted of a total of 35 questions and took approximately 20-30 minutes to complete. Once the data were collected, they were verified by cross comparison of 10 randomly selected hard copies of the dataset with entered data.

Data were analysed using SPSS, version 21. Chisquared and the Fisher exact test were used to assess the relationship between categorical variables and to check the correlation between socioeconomic variables and stress-inducing factors. The results were considered significant at $P<0.05$.

Ethical approval was taken from the institutional review board of Jinnah Sindh Medical University, Karachi (approval letter no. JSMU/IRB/2015/-22). Before initiating the survey, we briefed the munshi (time keeper/focal person) who monitors the arrival and departure of buses at major bus stands/stops in detail to keep them informed regarding the purpose and objectives of the study. Informed consent (both verbal and written) was obtained from all participating drivers before administering the questionnaire, and participants were informed that they were free to withdraw their participation at any time during the study.

\section{Results}

A total of 384 occupational drivers completed the questionnaire. The mean age was 36.80 [standard deviation (SD) 10.74] years (Table 1); 220 (57.3\%) of the drivers were $\leq 37$ years old while $164(42.7 \%)$ were $>37$ years. The religion of $381(99.2 \%)$ drivers was Islam; only 3 (0.8\%) belonged to other religions. Among all the participants, 233 $(60.7 \%)$ were able to read and write. The mean number of family members of the occupational drivers was 6.65 (SD 2.32); 253 (65.9\%) with $\leq 7$ family members and 131
Table 1 Sociodemographic characteristics of the occupation drivers in the study sample $(n=384)$, Karachi, 2017

\begin{tabular}{|c|c|c|}
\hline Sociodemographic characteristics & No. & $\%$ \\
\hline Age (years) $(n=384)$ & \multicolumn{2}{|c|}{$36.80(0.74)^{\mathrm{a}}$} \\
\hline$\leq 37$ & 220 & 57.3 \\
\hline$>37$ & 164 & 42.7 \\
\hline \multicolumn{3}{|l|}{ Religion $(n=384)$} \\
\hline Islam & 381 & 99.2 \\
\hline Other & 3 & 0.8 \\
\hline \multicolumn{3}{|l|}{ Education status (n = 384) } \\
\hline No formal education & 151 & 39.3 \\
\hline Formal education & 233 & 60.7 \\
\hline No. household members $(n=384)$ & \multicolumn{2}{|c|}{$6.65(2.32)^{\mathrm{a}}$} \\
\hline$\leq 7$ & 253 & 65.9 \\
\hline$>7$ & 131 & 34.1 \\
\hline $\begin{array}{l}\text { Total monthly household income } \\
\text { (PKR) ( } n=384)\end{array}$ & \multicolumn{2}{|c|}{$21507(5552)^{a}$} \\
\hline$\leq 20000$ & 231 & 60.2 \\
\hline$>20000$ & 153 & 39.8 \\
\hline \multicolumn{3}{|l|}{ Mother language $(\mathrm{n}=384)$} \\
\hline Urdu & 158 & 41.1 \\
\hline Pushto & 82 & 21.4 \\
\hline Punjabi & 43 & 11.2 \\
\hline Hindko & 50 & 13 \\
\hline Sindhi & 24 & 6.3 \\
\hline Other & 27 & 7 \\
\hline \multicolumn{3}{|l|}{ Any substance abuse $(n=384)$} \\
\hline Yes & 259 & 67.4 \\
\hline No & 125 & 32.6 \\
\hline \multicolumn{3}{|l|}{ Substance use $(n=259)$} \\
\hline Acacia catechu products & 117 & 30.5 \\
\hline Quid (naswar) & 73 & 19 \\
\hline Cigarettes & 68 & 17.7 \\
\hline $\begin{array}{l}\text { No. of packs (quids/cigarettes) } \\
\text { per day }(n=261)\end{array}$ & \multicolumn{2}{|c|}{$2.85(2.55)^{\mathrm{a}}$} \\
\hline$\leq 3$ & 164 & 62.8 \\
\hline$>3$ & 97 & 37.2 \\
\hline \multicolumn{3}{|l|}{ Occupation history $(n=384)$} \\
\hline Hours of driving per day & \multicolumn{2}{|c|}{$11.93(2.38) \mathrm{a}$} \\
\hline$\leq 12$ & 277 & 277 \\
\hline$>12$ & 107 & 107 \\
\hline \multicolumn{3}{|l|}{ Years of driving } \\
\hline$\leq 13$ & 164 & 62.8 \\
\hline$>13$ & 97 & 37.2 \\
\hline
\end{tabular}

PKR = Pakistani rupees.

(34.1\%) had $>7$ family members. The mean total monthly household income of drivers was 21507 (SD 5552) Pakistani rupees (Table 1).

Substance abuse was found in 259 (67.4\%) occupational drivers; 117 (30.5\%) used Acacia catechu products, 73 (19\%) used quid (naswar) and 68 (17.7\%) smoked cigarettes 
(Table 1). The mean number of packs (quids/cigarette) used per day was 2.85 (SD 2.55); 97 drivers (37.2\%) used $>3$ packs per day.

The mean hours of driving per day was 11.93(SD 2.38) hours; $107(27.9 \%)$ drove $>12$ hours each day. The mean number of years participants had been driving was 12.87 (SD 8.75); 150 (39.1\%) had > 13 years of driving experience (Table 1).

Traffic jam was the most common cause of stress among occupational drivers and was reported by 377 (98.2\%) occupational drivers, followed by poor condition (potholes) of the roads in 356 (92.7\%), lights of other vehicles in $339(88.3 \%)$ and load shedding of compressed natural gas (CNG) in 327 (85.2\%) (Table 2) Misbehaviour of passengers and slow passengers were reported as stressinducers by only $32(8.3 \%)$ and $29(7.6 \%)$ occupational drivers, respectively (Table 2).

Stress was considered to be affecting the abrupt acceleration or deceleration of the vehicle by $212(55.2 \%)$ occupational drivers, accidents by $263(68.5 \%)$ and traffic jam by 199 (51.8\%) (Table 3).

Total monthly income was the only factor statistically significantly associated with unsafe behaviour of other drivers in causing stress $(P<0.001)$ (Table 4$)$. On the other hand, mother language $(P=0.002)$ and any form of substance abuse $(P=0.02)$ were significantly associated with pressure of time as a stress-inducing factor. Only substance abuse (as a stress-inducing factor) was significantly associated with fear of accidents $(P<0.001)$.

Of the sociodemographic variables, only number of household members was significantly associated with misbehaviour of passengers in inducing stress $(P=0.01)$, and only age was significantly associated with traffic police or police as a cause of stress $(P=0.02)$. None of the sociodemographic characteristics were found to be associated with condition of roads and load shedding of $\mathrm{CNG}$ as a stress-inducing factor. Education status $(P=0.042)$ was the only factor significantly associated

\begin{tabular}{llc}
\hline $\begin{array}{l}\text { Table } 2 \text { Factors contributing to stress among occupational } \\
\text { drivers ( } \boldsymbol{n}=\mathbf{3 8 4} \text { ), Karachi, } \mathbf{2 0 1 7}\end{array}$ & No. & $\%$ \\
\hline Stress-inducing factors & 234 & 60.9 \\
\hline Unsafe behaviour of other drivers at road & 320 & 83.3 \\
Pressure of time & 281 & 73.2 \\
Fear of accidents & 29 & 7.6 \\
Slow passengers & 32 & 8.3 \\
Misbehaviour of passengers & 356 & 92.7 \\
Poor condition of road & 327 & 85.2 \\
Load shedding of CNG & 281 & 73.2 \\
Traffic police & 278 & 72.4 \\
Fear of cell phone or money snatching & 339 & 88.3 \\
Lights of others vehicle & 300 & 78.1 \\
Pollution & 377 & 98.2 \\
\hline Traffic jam & & \\
\hline
\end{tabular}

CNG $=$ compressed natural gas.

\begin{tabular}{|c|c|c|}
\hline Impact of stress & No. & $\%$ \\
\hline \multicolumn{3}{|c|}{ Abrupt acceleration or deceleration } \\
\hline Yes & 212 & 55.2 \\
\hline No & 172 & 44.8 \\
\hline \multicolumn{3}{|l|}{ Cognitive failure } \\
\hline Yes & 186 & 48.4 \\
\hline No & 198 & 51.6 \\
\hline \multicolumn{3}{|l|}{ Aggressive driving } \\
\hline Yes & 168 & 43.8 \\
\hline No & 216 & 56.3 \\
\hline \multicolumn{3}{|l|}{ Trafficjam } \\
\hline Yes & 199 & 51.8 \\
\hline No & 185 & 48.2 \\
\hline \multicolumn{3}{|l|}{ Accident } \\
\hline Yes & 263 & 68.5 \\
\hline No & 121 & 31.5 \\
\hline \multicolumn{3}{|c|}{ Negative effect on performance } \\
\hline Yes & 171 & 44.5 \\
\hline No & 213 & 55.5 \\
\hline
\end{tabular}

with fear of cell phone or money snatching as a stress-inducing factor and none of the reported sociodemographic variables was found to be associated with lights of other vehicles, pollution or traffic jam as a stress-inducing factor (Table 4).

Abrupt acceleration or deceleration due to stress $(P=$ 0.007), aggressive driving $(P<0.001)$ and negative effect on performance $(P<0.001)$ were significantly associated with the type of vehicle being used and posed an impact of stress on the driving performance of occupational drivers (Table 5).

\section{Discussion}

Our findings clearly indicate that the most common cause of stress among occupational drivers is traffic jams, which is consistent with findings reported in earlier studies conducted in developing countries (18-20). The noteworthy increase in traffic congestion in Karachi is due to the rapid increase in the number of vehicles on the road, which ultimately resulted in increased traffic problems (21). This not only worsens the traffic condition but also adds to the huge increases in air pollution, noise pollution and overcrowding, and results in long periods of delay on the roads.

Another potential cause for the increased traffic congestion is that at many locations in Karachi a large volume of passengers, hawkers and stalls or handcarts have occupied the road spaces, making it difficult for traffic flow. In addition, double parking on the main roads in all the commercial areas has greatly increased the traffic problem (22). Although, the government has provided multistorey car parks, these fail to cover even 


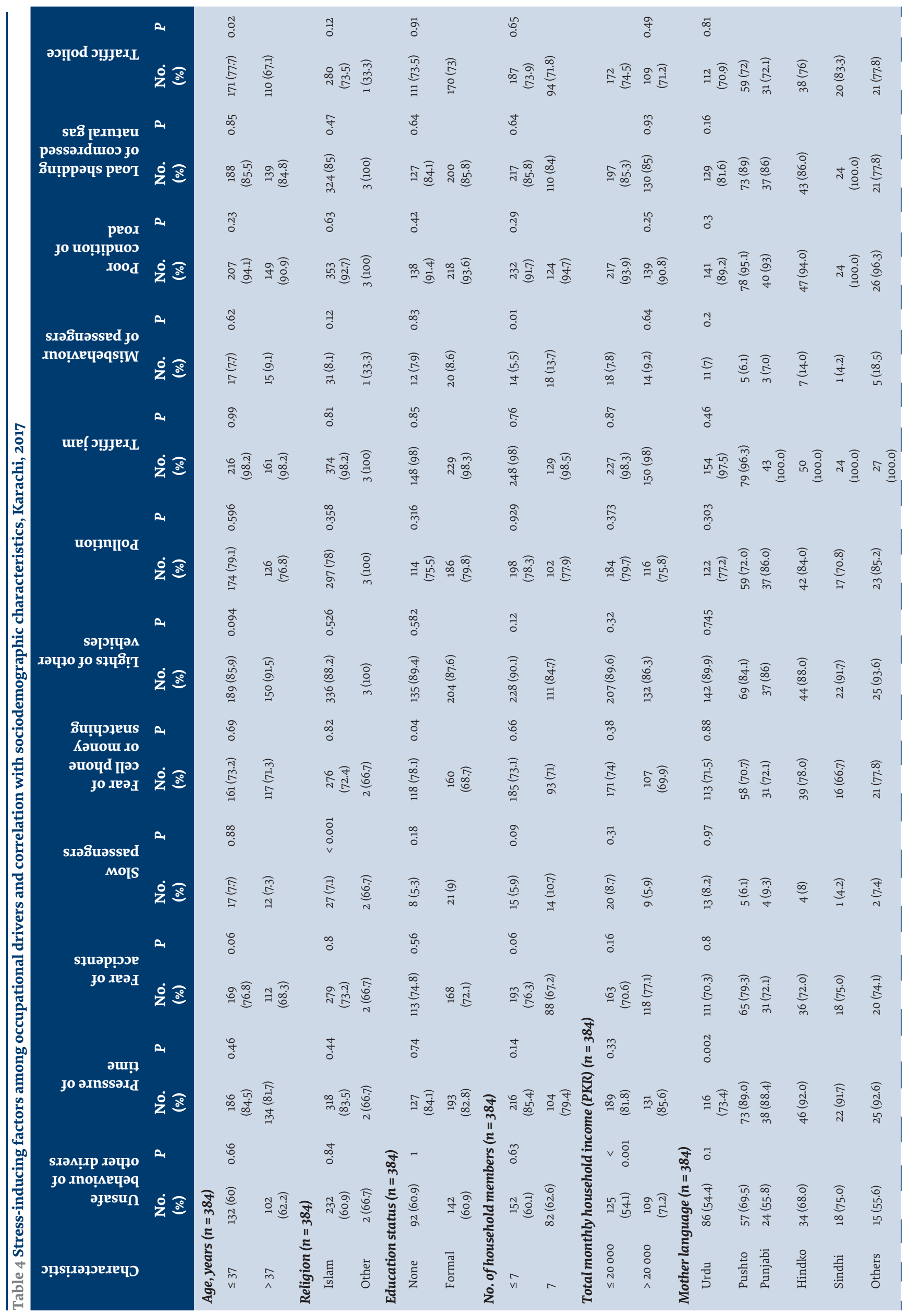




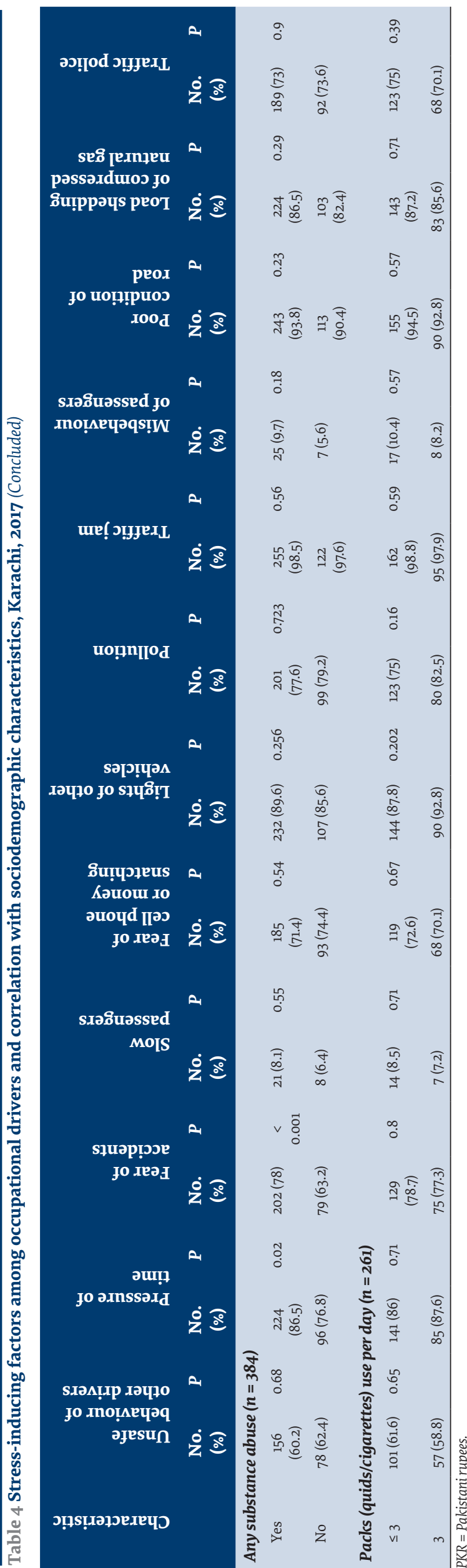

one fourth of the vehicles in a metropolitan city like Karachi (23). All these conditions create chaos on the roads of Karachi, and consequently result in traffic jams and stress among occupational drivers (21).

Additionally, a large number of occupational drivers reported poor condition of the roads, pressure of time, flashing of lights into the eyes by other vehicles and load shedding of CNG as factors that caused them stress. A similar study conducted among bus drivers in Bogotá, Colombia elucidated that adverse condition of roads can generate risky driving behaviours and can also be a considerable source of job strain (24). Although, more than half the respondents affirmed that fear of accidents was an important stress factor, the condition of roads was mentioned as a predominant stress-causing factor that ultimately led to psychological illness among occupational drivers.

Pressure of time and fear of accidents as stressinducing factors were greater among those using any form of substance abuse. The respondents of this study reported using gutka (chewable tobacco) and cigarettes as a form of substance abuse; this may be because of the high levels of work-related psychosocial risk factors they face, as suggested in other studies $(25,26)$. This further invites researchers to explore the pattern of coping strategies and chronic stress and substance abuse while driving among occupational drivers.

Many participants considered confrontation with traffic police as a substantial source of stress. Young drivers were more prone to be stressed while confronting traffic police as compared to older drivers. However, in contrast with our findings, $70 \%$ of Spanish drivers in another study responded that police supervision was effective in promoting road safety and law enforcement among drivers (27), implying that they did not consider it a stress factor while driving. In a developing country like Pakistan, it is alleged that the police are corrupt: they take informal payments (bribes) from drivers who break traffic rules and regulations (21); this may be one of the reasons police confrontation is a stress inducer for drivers. Therefore, it is crucially important to discourage such malpractices in Pakistan as parallel studies report that less-experienced drivers have a higher risk of road accidents (28).

Pressure of time was also considered a significant factor causing stress among occupational drivers during rush hours. This factor is more pronounced during traffic jams or due to the poor condition of the roads. Research has shown that time pressure has become a cultural phenomenon that goes beyond a personality factor (29). Moreover, to cope with this problem in a mega city such as Karachi, there is a dire need to build signal-free roads and flyovers so that traffic congestion can be reduced (21). However, it is essential to improve mobility across public spaces by ensuring traffic safety. Governmentled comprehensive strategies to develop the city's public transport system seems to be a promising solution for the alarming traffic situation in the city. 


\begin{tabular}{|c|c|c|c|c|c|c|}
\hline $\begin{array}{l}\text { Impact of stress on driving } \\
\text { performance }\end{array}$ & $\begin{array}{c}\text { Bus } \\
\text { No. (\%) }\end{array}$ & $\begin{array}{l}\text { Rickshaw } \\
\text { No. (\%) }\end{array}$ & $\begin{array}{c}\text { Taxi } \\
\text { No. (\%) }\end{array}$ & $\begin{array}{l}\text { Private } \\
\text { vehicle } \\
\text { No. }(\%)\end{array}$ & $\begin{array}{c}\text { Total } \\
\text { No (\%) }\end{array}$ & $\boldsymbol{P}$ \\
\hline Abrupt acceleration or deceleration & $45(21)$ & $66(31)$ & $55(26)$ & $46(22)$ & $212(100)$ & 0.007 \\
\hline Cognitive failure & $44(24)$ & $52(28)$ & $48(26)$ & $42(23)$ & $186(100)$ & 0.496 \\
\hline Aggressive driving & $44(26)$ & $65(39)$ & $31(19)$ & $28(17)$ & $168(100)$ & $<0.001$ \\
\hline Traffic jam & $48(24)$ & $47(24)$ & $46(23)$ & $58(29)$ & 199 (100) & 0.276 \\
\hline Accident & $74(28)$ & $69(26)$ & $59(22)$ & $61(23)$ & $263(100)$ & 0.069 \\
\hline Negative effect on performance & $34(20)$ & $63(37)$ & $32(19)$ & $42(25)$ & $171(100)$ & $<0.001$ \\
\hline
\end{tabular}

In the current study, none of the occupational drivers reported that they had any disease or health problem in the previous 6 months, including any mental or psychological problems. Contrary to this, a study conducted among bus drivers in Mumbai, India, revealed that hypertension, musculoskeletal problems and gastrointestinal diseases were the results of occupational stress among the study population (30). The factors identified were primarily shift schedule, irregular timings of food intake, compromised nutrition, long hours of driving and traffic jams causing occupation-related stress (30).

In our study more than $50 \%$ of the respondents reported that the impact of stress led them to abrupt acceleration or deceleration and more than a quarter reported cognitive failure as an impact of stress on their driving performance. A study was conducted among drivers in Japan which aimed to educate them on controlling their emotions and to identify stressors that induce a negative reaction on their skills while driving, including abrupt acceleration or deceleration, aggressive driving and cognitive failure (17). The findings revealed that most of the drivers who were aged $>37$ years tended to be less affected by such stressors as they were more experienced and could cope better with stressors and situations affecting their driving (17). In order to reduce road traffic accidents, work stress should be minimized as it is associated with abnormal driving behaviours and consequently causes physical and mental fatigue in drivers leading to a combination of problems such as lack of psychological alertness, poor decision-making and visual impairment.

Additionally, a study project conducted among PanEuropeans found that behaviour of drivers, specifically deceleration, was mainly due to detecting danger on the road followed by hard braking that resulted in slowing of the vehicle (31). Thus, anxiety and stress play a major role defining the behaviour of drivers while driving. This anxiety can be reduced if educational programmes are introduced which focus on enhancing the skills of young drivers to allow them to acquire a balanced emotional state and to be better aware of changes in the driving environment.

Risky behaviour of experienced drivers while driving have been found to be a notable cause of road accidents and unnatural deaths. In a comparative study conducted in Bogota, Columbia, errors while driving and traffic violations were correlated with risky behaviour among experienced drivers (28). Similar studies have reported that risky behaviour is directly proportional to an individual's attitudes, habits, behaviour and specific performance factors $(20,24)$. In contrast to earlier studies, we found that only age was correlated with considering traffic police as a stress-inducing factor resulting in risky behaviour while driving. Some research has looked into interventions such as training opportunities to allow new or young, inexperienced drivers to learn how to detect and respond to potential hazards or stress inducers (32). The result of such interventions indicates that this skill is trainable and the learned knowledge can be transferred and applied to new or unseen driving environments.

In the present study, unsafe behaviours in other drivers was a source of stress among occupational drivers leading to road accidents and near miss incidents, which is consistent with the findings of a study conducted in Malaysia (33). However, the distance travelled per day by the study participants was also a prominent factor leading to unsafe driving attributes. Overall, certain characteristics of occupational drivers such as education status, religion and substance abuse were correlated with fear of accidents and the condition of roads as stressinducing factors, but there seems to be a paucity in the literature on this and little attention has been paid to these issues in previous studies on occupational drivers. As a future strategy, systematic and comparative analysis should be employed for evidence aimed at policies designed for driving behaviours as well as for training purposes.

Caution is advised when interpreting our findings as we used a questionnaire-based, cross-sectional survey, which cannot further assess any temporal association between a risk factor and an outcome to determine the cause and effect relationship. Also, the study results cannot be generalized since nonprobability quota sampling was used; this limits the generalizability of the study findings as the participants were not randomly selected. Generalizability is also compromised because of the small sample size in relation to the thousands of professional drivers in Karachi. Lastly, the selfadministered questionnaire can also be considered a limitation of this study as it requires a greater level of 
literacy than an interview and at times the participants may have understood and interpreted the questions differently

\section{Conclusion}

The study highlighted the major stress-inducing factors which trigger risky driving behaviours among occupational drivers, increasing the likelihood of road accidents. Fortunately, all the identified stress-inducing factors identified in the current study are controllable and can be addressed with appropriate strategies and measures. If supported by further research, our findings can help develop policies to reduce stressors among occupational drivers and potentially contribute towards developing prevention strategies targeted at reducing road traffic clashes associated with stress in occupational drivers of Karachi.

Funding: None.

Competing interests: None declared.

\section{Facteurs de stress chez les conducteurs professionnels à Karachi (Pakistan) \\ Résumé}

Contexte: Le stress lié au travail est devenu un problème mondial de santé publique chez les conducteurs professionnels. Cependant, ce problème est amplement négligé dans la population pakistanaise.

Objectifs : La présente étude a été menée afin d'identifier les facteurs de stress chez les conducteurs professionnels à Karachi et de déterminer le lien entre les sources de stress et les facteurs sociodémographiques et professionnels chez les conducteurs de bus, minibus, pouss-pousse, taxi et véhicules privés.

Méthodes: Une étude transversale a été menée de février à octobre 2017 à l'aide d'un questionnaire structuré validé. $\mathrm{Au}$ total, 384 conducteurs ont été recrutés à l'aide d'un échantillonnage non aléatoire par quota. Les informations obtenues portaient sur les caractéristiques sociodémographiques, les antécédents médicaux et les facteurs de stress de ces derniers. Une analyse statistique a été réalisée à l'aide du logiciel SPSS 21. Le test du khi carré a été utilisé pour mettre en évidence l'association entre les variables catégorielles.

Résultats : La source de stress principale était les embouteillages $(n=377,98,2 \%)$, suivie par l'état des routes $(n=356$, $92,7 \%$ ), puis par les feux des autres véhicules ( $n=339,88,3 \%$ ).

Conclusions : Les conducteurs professionnels à Karachi connaissent de nombreux facteurs de stress. Il peut en résulter une baisse de précision et de capacité à conduire, augmentant ainsi le nombre d'accidents.

$$
\begin{aligned}
& \text { العوامل المُسببة للإجهاد في صفوف السائقين المهنيين في كراتشي، باكستان } \\
& \text { رزا حممد شاهر رخ، ميهاك بيرفيز، ناوشابا خاتون }
\end{aligned}
$$

الخلفية: أصبح الإجهاد المرتبط بالعمل مشكلةً من مشكلات الصحة العامة على الصعيد العالمي بين السائقين المهنيين، غير أنه موضوع مهمل للغاية لدى السكان الباكستانيين. الإجهاد المرتط.

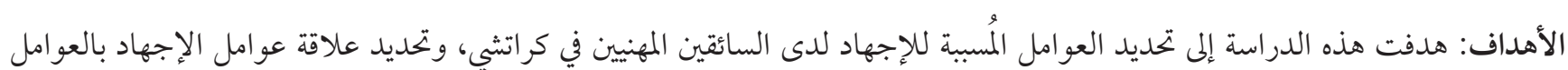

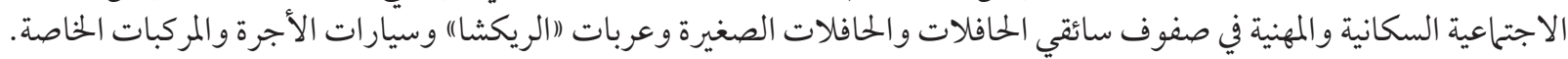

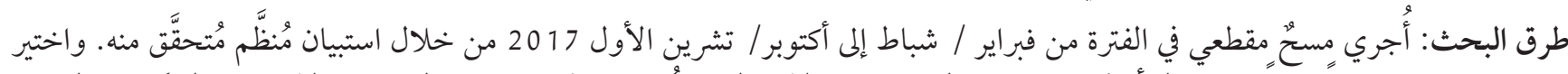

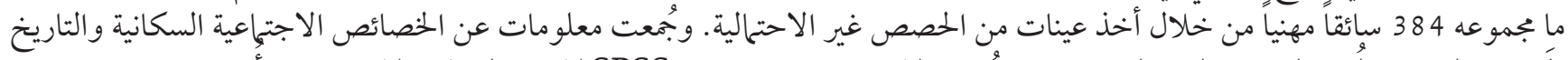

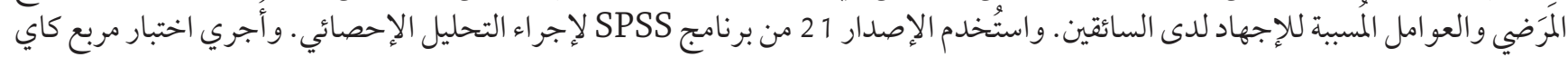
لمعرفة العلاقة بين المتغيرات المئوية. الثتائج: كان الاختناق المروري السبب الأكثر أهمية للإجهاد (العدد = 377، 3. 3.

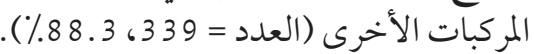

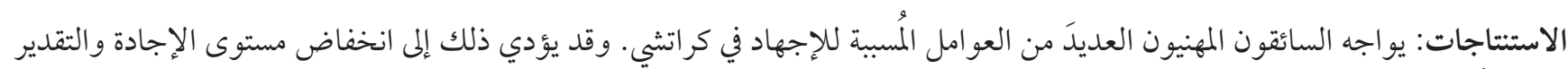

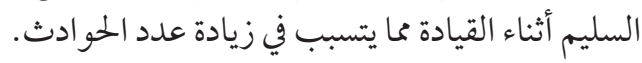




\section{References}

1. Cooper CL and Marshall J. Occupational sources of stress: a review of the literature relating to coronary heart disease and mental ill health. From Stress to Wellbeing. 2013;1:3-23. https://doi.org/10.1057/9781137310651_1

2. Bamber MR. Overcoming your workplace stress: a CBT-based self-help guide. London: Routledge; 2013. doi:10.1017/ S1352465813000106

3. Elder CR, Gullion CM, Funk KL, DeBar LL, Lindberg NM, Stevens VJ. Impact of sleep, screen time, depression and stress on weight change in the intensive weight loss phase of the LIFE study. Int J Obes. 2012;36(1):86. doi:10.1038/ijo.2011.60.

4. Seibokaite L, Endriulaitiene A. The role of personality traits, work motivation and organizational safety climate in risky occupational performance of professional drivers. Baltic J Management. 2012;7(1):103-18. doi:10.1108/17465261211195892

5. Sugiyama T, Wijndaele K, Koohsari MJ, Tanamas SK, Dunstan DW, Owen N. Adverse associations of car time with markers of cardio-metabolic risk. Prev Med. 2016;83:26-30. doi:10.1016/j.ypmed.2015.11.029.

6. Ding D, Gebel K, Phongsavan P, Bauman AE, Merom D. Driving: a road to unhealthy lifestyles and poor health outcomes. PloS One. 2014;9(6):e946020. doi:10.1371/journal.pone.0094602.

7. Rahmani A, Khodaei R, Farjami A, Mahmodkhani S, Gharagozlou F, Ahmadnezhad I, et al. Determination of job stresses and their consequences in drivers in Ilam. Electron Physician. 2013;5(1):594-8. doi:10.14661/2013.594-598

8. Abbas AK, Hefny AF, Abu-Zidan FM. Seatbelts and road traffic collision injuries. World J Emergency Surgery. 2011;6(1):18. https:// doi.org/10.1186/1749-7922-6-18

9. Ge Y, Qu W, Jiang C, Du F, Sun X, Zhang K. The effect of stress and personality on dangerous driving behavior among Chinese drivers. Accid Anal Prev. 2014;73:34-40. doi:10.1016/j.aap.2014.07.024.

10. Öz B, Özkan T and Lajunen T. Professional and non-professional drivers' stress reactions and risky driving. Transp Res Part F Traffic Psychol Behav. 2010;13:32-40. doi:10.1016/j.trf.2009.10.001

11. Costa G. Stress of driving: general overview. G Ital Med Lav Ergon. 32012;4(3):348-51.

12. Minhas MS, Sangani MM, Mehmood K, Bhatti A, Mughal A, Kumar R. Dupatta (long scarf) related injuries in female pillion riders in Karachi Pakistan. J Pak Med Assoc. 2016;66(11):1458-61.

13. Ma M, Yan X, Huang H, Abdel-Aty M, eds. Occupational driver safety of public transportation: risk perception, attitude, and driving behavior. J Transportation Res Board. 2010;2145(3):72-9.

14. Qureshi S. The fast growing megacity Karachi as a frontier of environmental challenges: urbanization and contemporary urbanism issues. J Geog Regional Plan. 2010;3(11):306.

15. Buron KD, Curtis M. The incredible 5-point scale: assisting students with autism spectrum disorders in understanding social interactions and controlling their emotional responses. Shawnee Mission, Kansas: Autism Asperger Publishing Company; 2003.

16. Kompier MA. Bus drivers: occupational stress and stress prevention. Geneva: International Labour Office; 1996.

17. Nakai H, Ogawa K. [Stress reactions among bus drivers: towards the development of an educational resource for better management of emotions]. Shinrigaku Kenkyu. 2014;85(4):373-82 (in Japanese).

18. Mrema G, ed. Traffic congestion in Tanzanian major cities: causes, impact and suggested mitigations to the problem. Proceedings of the 26th National Conference: Challenges in addressing traffic congestion and enhancing road safety for national development, 1-2 December 2011. Arusha: Tanzania; 2011.

19. Olagunju K, ed. Evaluating traffic congestion in developing countries: a case study of Nigeria. Paper presented at the 2015 Chartered Institute of Logistics and Transport Africa Forum, Arusha, Tanzania. Abuja: Federal Roads Safety Corp; 2015.

20. Ruiz-Grosso P, Ramos M, Samalvides F, Vega-Dienstmaier J, Kruger H. Common mental disorders in public transportation drivers in Lima, Peru. PloS one. 2014;9(6):e101066. https://doi.org/10.1371/journal.pone.0101066

21. Hasan A, Raza M. Responding to the transport crisis in Karachi. IIED and Urban Resource Center; 2015 (http://pubs.iied org/10733IIED html, accessed 13 March 2020).

22. Hasan A, Polak AS, Polak C. The hawkers of Saddar Bazaar: a plan for the revitalisation of Saddar Bazaar Karachi throughtraffic rerouting and the rehabilitation of its hawkers. Karachi: Ushba Publishing International; 2008.

23. Karim Z, Qureshi BA, Mumtaz M, Qureshi S. Heavy metal content in urban soils as an indicator of anthropogenic and natural influences on landscape of Karachi-a multivariate spatio-temporal analysis. Ecol Indic. 2014;42:20-31.

24. Useche SA, Ortiz VG, Cendales BE. Stress-related psychosocial factors at work, fatigue, and risky driving behavior in bus rapid transport (BRT) drivers. Accident Analysis Prev. 2017;104:6-14. doi:10.1016/j.aap.2017.04.023.

25. Useche SA, Cendales B, Gómez V. Measuring fatigue and its associations with job stress, health and traffic accidents in professional drivers: the case of BRT operators. Neurol. 2017;4(4):103-18.

26. Lim SM, Chia SE. The prevalence of fatigue and associated health and safety risk factors among taxi drivers in Singapore. Singapore Med J. 2015;56(2):92-7. doi:10.11622/smedj.2014169

27. Alonso F, Esteban C, Montoro L, Useche SA. Knowledge, perceived effectiveness and qualification of traffic rules, police supervision, sanctions and justice. Cogent Soc Sci. 2017;3(1):1393855. https://doi.org/10.1080/23311886.2017.1393855 
28. Useche S, Serge A, Alonso F. Risky behaviors and stress indicators between novice and experienced drivers. Am J Psychology. 2015;3(1):11-4.

29. Coeugnet S, Charron C, Van De Weerdt C, Anceaux F, Naveteur J. Time pressure: a complex phenomenon that needs to be studied as a matter of urgency. Travail Humain. 2011;74(2):157-81. doi:10.3917/th.742.0157

30. Taklikar C. Occupational stress and its associated health disorders among bus drivers. Int J Community Med Public Health. 2017;3(1):208-11. doi:http://dx.doi.org/10.18203/2394-6040.ijcmph20151564

31. Deligianni SP, Quddus M, Morris A, Anvuur A, Reed S. Analyzing and modeling drivers' deceleration behavior from normal driving. Transportation Res Record. 2017;2663:134-41. https://doi.org/10.3141/2663-17

32. Garay-Vega L, Fisher D, Pollatsek A. Hazard anticipation of novice and experienced drivers: empirical evaluation on a driving simulator in daytime and nighttime conditions. Transportation Res Record. 2009;(1):1-7. https://doi.org/10.3141/2009-01

33. Mahdi NNRN, Mohamed N, Shafei MN. Risk factors for near miss incident among long distance bus drivers in Malaysia. Iran J Public Health. 2015;43(3):117-24. 